\title{
EXTENDED CONTENTS
}

List of contributors xiii

Foreword liv

Table of cases Ivi

Table of legislation and international instruments $\quad$ xcviii

\section{PART I COMMENTARY ON THE CONVENTION}

$\begin{array}{ll}\text { THE PREAMBLE OF THE ICSID CONVENTION } & 0.01\end{array}$

1 INTERNATIONAL CENTRE FOR SETTLEMENT OF INVESTMENT DISPUTES 1.01

SECTION 1 ESTABLISHMENT AND ORGANIZATION 1.01

$\begin{array}{lr}\text { ARTICLE } 1 & 1.01\end{array}$

$\begin{array}{ll}\text { ARTICLE } 2 & 1.10\end{array}$

$\begin{array}{ll}\text { ARTICLE } 3 & 1.14\end{array}$

SECTION 2 THE ADMINISTRATIVE COUNCIL $\quad 1.18$

ARTICLE 4 1.18

$\begin{array}{lr}\text { ARTICLE } 5 & 1.25\end{array}$

$\begin{array}{lr}\text { ARTICLE } 6 & 1.32\end{array}$

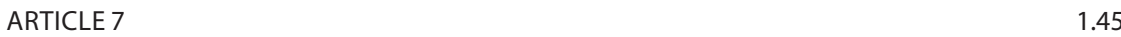

$\begin{array}{lr}\text { ARTICLE } 8 & 1.56\end{array}$

$\begin{array}{llr}\text { SECTION } 3 & \text { THE SECRETARIAT } & 1.58\end{array}$

ARTICLE $9 \quad 1.58$

$\begin{array}{lr}\text { ARTICLE } 10 & 1.70\end{array}$

ARTICLE $11 \quad 1.100$

$\begin{array}{llr}\text { SECTION } 4 & \text { THE PANELS } & 1.119\end{array}$

$\begin{array}{lr}\text { ARTICLE } 12 & 1.119\end{array}$

$\begin{array}{ll}\text { ARTICLE } 13 & 1.127\end{array}$

ARTICLE $14 \quad 1.138$

ARTICLE $15 \quad 1.152$

ARTICLE $16 \quad 1.156$

SECTION 5 FINANCING THE CENTRE $\quad 1.159$

ARTICLE $17 \quad 1.159$

$\begin{array}{llr}\text { SECTION } 6 \text { STATUS, IMMUNITIES AND PRIVILEGES } & 1.187\end{array}$

ARTICLE $18 \quad 1.189$

ARTICLE $19 \quad 1.201$

ARTICLE 20 1.205

ARTICLE 21 $\quad 1.210$

ARTICLE 22

ARTICLE 23 1.242

$\begin{array}{ll}\text { ARTICLE } 24 & 1.250\end{array}$ 
2 JURISDICTION OF THE CENTRE $\quad 2.01$

$\begin{array}{lr}\text { ARTICLE 25(1) } & 2.01\end{array}$

$\begin{array}{lr}\text { ARTICLE 25(2)(A) } & 2.108\end{array}$

$\begin{array}{lr}\text { ARTICLE 25(2)(B) } & 2.149\end{array}$

$\begin{array}{ll}\text { ARTICLE 25(3) } & 2.206\end{array}$

ARTICLE 25(4) 2.233

ARTICLE $26 \quad 2.255$

ARTICLE $27 \quad 2.302$

3 CONCILIATION 3.01

SECTION 1 REQUEST FOR CONCILIATION $\quad 3.01$

$\begin{array}{lr}\text { ARTICLE } 28 & 3.01\end{array}$

SECTION 2 CONSTITUTION OF THE CONCILIATION COMMISSION

$\begin{array}{lr}\text { ARTICLE } 29 & 3.17\end{array}$

$\begin{array}{lr}\text { ARTICLE } 30 & 3.17\end{array}$

ARTICLE $31 \quad 3.17$

SECTION 3 CONCILIATION PROCEEDINGS

ARTICLE $32 \quad 3.28$

ARTICLE $33 \quad 3.28$

ARTICLE $34 \quad 3.28$

ARTICLE 35

4 ARBITRATION $\quad 4.01$

SECTION 1 REQUEST FOR ARBITRATION $\quad 4.01$

ARTICLE $36 \quad 4.01$

SECTION 2 CONSTITUTION OF THETRIBUNAL $\quad 4.50$

ARTICLE $37 \quad 4.50$

ARTICLE $38 \quad 4.95$

$\begin{array}{lr}\text { ARTICLE } 39 & 4.123\end{array}$

ARTICLE $40 \quad 4.154$

SECTION 3 POWERS AND FUNCTIONS OF THETRIBUNAL $\quad 4.174$

ARTICLE $41 \quad r .174$

$\begin{array}{lr}\text { ARTICLE } 42 & 4.241\end{array}$

ARTICLE $43 \quad 4.294$

$\begin{array}{lr}\text { ARTICLE } 44 & 4.341\end{array}$

$\begin{array}{lr}\text { ARTICLE } 45 & 4.371\end{array}$

$\begin{array}{lr}\text { ARTICLE } 46 & 4.430\end{array}$

$\begin{array}{lr}\text { ARTICLE } 47 & 4.481\end{array}$

SECTION 4 THE AWARD $\quad 4.684$

ARTICLE $48 \quad r .684$

ARTICLE $49 \quad 4.794$

SECTION 5 INTERPRETATION, REVISION AND ANNULMENT OF THE AWARD 4.850

ARTICLE $50 \quad 4.850$

$\begin{array}{ll}\text { ARTICLE } 51 & 4.861\end{array}$

ARTICLE 52(1) $\quad 4.940$

ARTICLE 52(1)(A) $\quad 4.967$

ARTICLE 52(1)(B) $\quad 4.986$

$\begin{array}{ll}\text { ARTICLE 52(1)(C) } & 4.1019\end{array}$

$\begin{array}{ll}\text { ARTICLE 52(1)(D) } & 4.1033\end{array}$

$\begin{array}{ll}\text { ARTICLE 52(1)(E) } & 4.1078\end{array}$

$\begin{array}{ll}\text { ARTICLE 52(2) } & 4.1118\end{array}$

ARTICLE 52(3) $\quad 4.1130$

ARTICLE 52(4) $\quad 4.1156$

$\begin{array}{ll}\text { ARTICLE 52(5) } & 4.1173\end{array}$ 
ARTICLE 52(6)

SECTION 6 RECOGNITION AND ENFORCEMENT OF THE AWARD

ARTICLE 53

4.1291

ARTICLE 54

4.1335

ARTICLE 55

5 REPLACEMENT AND DISQUALIFICATION OF CONCILIATORS AND

ARBITRATORS

ARTICLE 56

ARTICLE 57

5.01

ARTICLE 58

5.01

6 COST OF PROCEEDINGS

6.01

ARTICLE 59

6.38

ARTICLE 60

6.45

ARTICLE 61

7 PLACE OF PROCEEDINGS

ARTICLE 62

ARTICLE 63

8 DISPUTES BETWEEN CONTRACTING STATES

9 AMENDMENT

ARTICLE 65

ARTICLE 66

10 FINAL PROVISIONS

10.01

ARTICLE 67

ARTICLE 68

10.10

ARTICLE 69

10.18

ARTICLE 70

10.25

ARTICLE 71

10.33

ARTICLE 72

10.33

ARTICLE 73

10.82

ARTICLE 74

10.89

ARTICLE 75

10.94

FINAL CLAUSE

\section{PART II COMMENTARY ON ADMINISTRATIVE AND FINANCIAL REGULATIONS}

12 PROCEDURES OF THE ADMINISTRATIVE COUNCIL 
REGULATION 4 - PRESIDING OFFICER

REGULATION 5 - SECRETARY OF THE COUNCIL

REGULATION 6 - ATTENDANCE AT MEETINGS

12.14

REGULATION 7 - VOTING

13 THE SECRETARIAT

REGULATION 8 - ELECTION OF THE SECRETARY-GENERAL AND HIS DEPUTIES

REGULATION 9 - ACTING SECRETARY-GENERAL

REGULATION 10 - APPOINTMENT OF STAFF MEMBERS

REGULATION 11 - CONDITIONS OF EMPLOYMENT

REGULATION 12 - AUTHORITY OF THE SECRETARY-GENERAL

REGULATION 13 - INCOMPATIBILITY OF FUNCTIONS

14 FINANCIAL PROVISIONS

REGULATION 14 - DIRECT COSTS OF INDIVIDUAL PROCEEDINGS

REGULATION 15 - SPECIAL SERVICES TO PARTIES

14.17

REGULATION 16 - FEE FOR LODGING REQUESTS

14.18

REGULATION 17 - THE BUDGET

REGULATION 18 - ASSESSMENT OF CONTRIBUTIONS

14.25

REGULATION 19 - AUDITS

15 GENERAL FUNCTIONS OF THE SECRETARIAT

16 FUNCTIONS WITH RESPECT TO INDIVIDUAL PROCEEDINGS

REGULATION 24 - MEANS OF COMMUNICATION

REGULATION 25 - SECRETARY

REGULATION 26 - PLACE OF PROCEEDINGS

16.10

REGULATION 27 - OTHER ASSISTANCE

17 SPECIAL PROVISIONS RELATING TO PROCEEDINGS

18 IMMUNITIES AND PRIVILEGES

19 MISCELLANEOUS 
PART III COMMENTARY ON RULES OF PROCEDURE FOR THE INSTITUTION OF CONCILIATION AND ARBITRATION PROCEEDINGS (INSTITUTION RULES)

20 RULES OF PROCEDURE FOR THE INSTITUTION OF CONCILIATION AND ARBITRATION PROCEEDINGS (INSTITUTION RULES) RULE 1 - THE REQUEST

RULE 2 - CONTENTS OF THE REQUEST

RULE 3 - OPTIONAL INFORMATION IN THE REQUEST

RULE 4 - COPIES OF THE REQUEST

RULE 5 - ACKNOWLEDGEMENT OF THE REQUEST

RULE 6 - REGISTRATION OF THE REQUEST

20.20

RULE 7 - NOTICE OF REGISTRATION

20.24

RULE 8 - WITHDRAWAL OF THE REQUEST

20.29

20.30

RULE 9 - FINAL PROVISIONS

\section{PART IV RULES OF PROCEDURE FOR ARBITRATION PROCEEDINGS (ARBITRATION RULES)}

21 ESTABLISHMENT OF THE TRIBUNAL 21.01

RULE 1 - GENERAL OBLIGATIONS

RULE 2 - METHOD OF CONSTITUTING THE TRIBUNAL IN THE ABSENCE OF PREVIOUS AGREEMENT

RULE 3 - APPOINTMENT OF ARBITRATORS TO A TRIBUNAL CONSTITUTED IN ACCORDANCE WITH CONVENTION ARTICLE 37(2)(B)

RULE 4 - APPOINTMENT OF ARBITRATORS BY THE CHAIRMAN OF THE ADMINISTRATIVE COUNCIL

RULE 5 - ACCEPTANCE OF APPOINTMENTS

RULE 6 - CONSTITUTION OF THE TRIBUNAL

RULE 7 - REPLACEMENT OF ARBITRATORS

RULE 8 - INCAPACITY OR RESIGNATION OF ARBITRATORS

RULE 9 - DISQUALIFICATION OF ARBITRATORS

RULE 10 - PROCEDURE DURING A VACANCY ON THE TRIBUNAL

RULE 11 - FILLING VACANCIES ON THE TRIBUNAL

RULE 12 - RESUMPTION OF PROCEEDING AFTER FILLING A VACANCY

22 WORKING OF THE TRIBUNAL

RULE 13 - SESSIONS OF THE TRIBUNAL

RULE 14 - SITTINGS OF THE TRIBUNAL

RULE 15 - DELIBERATIONS OF THE TRIBUNAL

RULE 16 - DECISIONS OF THE TRIBUNAL

RULE 17 - INCAPACITY OF THE PRESIDENT

RULE 18 - REPRESENTATION OF THE PARTIES

23 GENERAL PROCEDURAL PROVISIONS 
RULE 24 - SUPPORTING DOCUMENTATION

RULE 25 - CORRECTION OF ERRORS

RULE 26 - TIME LIMITS $\quad 23.46$

RULE 27 - WAIVER

RULE 28 - COST OF PROCEEDING 23.62

24 WRITTEN AND ORAL PROCEDURES $\quad 24.01$

$\begin{array}{ll}\text { RULE 29 - NORMAL PROCEDURES } & 24.01\end{array}$

RULE 30 - TRANSMISSION OF THE REQUEST $\quad 24.05$

RULE 31 - THE WRITTEN PROCEDURE $\quad 24.06$

RULE 32 - THE ORAL PROCEDURE $\quad 24.14$

RULE 33 - MARSHALLING OF EVIDENCE $\quad 24.20$

RULE 34 - EVIDENCE: GENERAL PRINCIPLES $\quad 24.27$

RULE 35 - EXAMINATION OF WITNESSES AND EXPERTS $\quad 24.40$

RULE 36 - WITNESSES AND EXPERTS: SPECIAL RULES $\quad 24.40$

RULE 37 - VISITS AND INQUIRIES; SUBMISSIONS OF NON-DISPUTING PARTIES $\quad 24.73$

$\begin{array}{ll}\text { RULE } 38 \text { - CLOSURE OF THE PROCEEDING } & 24.131\end{array}$

25 PARTICULAR PROCEDURES $\quad 25.01$

$\begin{array}{lr}\text { RULE } 39 \text { - PROVISIONAL MEASURES } & 25.01\end{array}$

$\begin{array}{ll}\text { RULE } 40 \text { - ANCILLARY CLAIMS } & 25.108\end{array}$

RULE 41 - PRELIMINARY OBJECTIONS $\quad 25.136$

RULE 42 - DEFAULT $\quad 25.196$

RULES 43-45 $\quad 25.221$

RULE 43 - SETTLEMENT AND DISCONTINUANCE $\quad 25.230$

RULE 44 - DISCONTINUANCE AT REQUEST OF A PARTY $\quad 25.267$

RULE 45 - DISCONTINUANCE FOR FAILURE OF PARTIES TO ACT $\quad 25.286$

26 THE AWARD $\quad 26.01$

$\begin{array}{ll}\text { RULE } 46 \text { - PREPARATION OF THE AWARD } & 26.01\end{array}$

RULE 47 - THE AWARD $\quad 26.25$

RULE 48 - RENDERING OF THE AWARD $\quad 26.70$

$\begin{array}{ll}\text { RULE } 49 \text { - SUPPLEMENTARY DECISIONS AND RECTIFICATION } & 26.97\end{array}$

27 INTERPRETATION, REVISION AND ANNULMENT OF THE AWARD 27.01

$\begin{array}{ll}\text { RULES 50-56 } & 27.01\end{array}$

RULE 50 - THE APPLICATION

RULE 51 - INTERPRETATION OR REVISION: FURTHER PROCEDURES $\quad 27.45$

RULE 52 - ANNULMENT: FURTHER PROCEDURES $\quad 27.52$

$\begin{array}{ll}\text { RULE } 53 \text { - RULES OF PROCEDURE } & 27.57\end{array}$

RULE 54 - STAY OF ENFORCEMENT OF THE AWARD $\quad 27.64$

RULE 55 - RESUBMISSION OF DISPUTE AFTER AN ANNULMENT $\quad 27.82$

$\begin{array}{ll}\text { RULE } 56 \text { - FINAL PROVISIONS } & 27.94\end{array}$

$\begin{array}{lr}\text { Select bibliography } & 1305\end{array}$

$\begin{array}{ll}\text { Index } & 1311\end{array}$ 